\title{
PENGEMBANGAN MODEL GERAK DASAR KETERAMPILAN MOTORIK UNTUK KELOMPOK USIA 6-8 TAHUN
}

\author{
Imam Mahfud', Rizki Yuliandra' \\ ${ }^{1}$ Universitas Teknokrat Indonesia. ${ }^{2}$ Universitas Teknokrat Indonesia
}

\begin{abstract}
ABSTRAK
Anak pada usia 6-8 tahun merupakan masa perkembangan motorik yang pesat. Dunia anak adalah dunia bermain dan belajarnya anak sebagian besar melalui permainan yang mereka lakukan.Tujuan yang ingin dicapai pada penelitian dan pengembangan ini adalah untuk menghasilkan produk model gerak dasar keterampilan motorik untuk kelompok usia 6-8 Tahun. Penelitian ini menggunakan metode Research \& Development (R\&D) dari Borg and Gall. Subyek dalam penelitian ini adalah anak usia 6-8 tahun.Uji efektifitas produk yaitu berdasarkan penilaian 2 orang ahli perkembangan motorik dan 1 orang ahli pembelajaran. Hasil yang didapatkan dari ketiga ahli adalah 88.6 yang dinyatakan baik dan layak untuk digunakan. Berdasarkan hasil pengembangan dapat disimpulkan, Berdasarkan hasil analisis berdasarkan penilaian ahli maka dapat disimpulkan bahwa bentuk pengembangan model gerak dasar motorik untuk usia 6-8 tahun ini layak digunakan. Hasil akhir dalam penelitian ini berupa buku panduan pelaksanaan item model gerak dasar motorik yang berisi tujuan, pelaksanaan, pengamatan, dan video pelaksanaan model gerak dasar motorik untuk usia 6-8 tahun
\end{abstract}

Kata Kunci: Pengembangan, Gerak Dasar, Motorik

\begin{abstract}
Children at the age of 6-8 years is a period rapid growth of motor skills. The world's children are playing and learning children's world largely through the game they do. The goal in this research and development is to produce products basic motion model of the motor skills to the age group of 6-8 Year, This study uses the Research \& Development ( $R$ \& $D$ ) of Borg and Gall. Subjects in this research were children aged 6-8 years. Test the effectiveness of the product is based on an assessment 2 motor development experts judgement and one learning expert judgement. The results obtained from the three experts is 88.6 which otherwise good and decent to use. Based on the results of the development can be concluded, According to analysis by an expert assessment it can be concluded that the form of basic motion models of motor development for 6-8 years of age is appropriate to use. The final result in this study a guidebook implementation of the basic motion models motor item that contains objectives, implementation, observation, and videos from the basic motion models motor for ages 6-8 years
\end{abstract}

Keywords: development, basic movements, motor

\section{PENDAHULUAN}

Perkembangan motorik sangat penting dalam tahapan perkembangan anak. Penguasaan bentuk perkembangan motorik halus dan motorik kasar sangat penting untuk tumbuh kembang dan melatih anak untuk hidup mandiri. Perbedaan antara 
motorik halus dan motorik kasar terdapat pada penggunaan otot dalam melakukan aktifitas. Motorik halus merupakan kemampuan yang berhubungan dengan keterampilan yang menggunakan otot kecil dan motorik kasar dengan menggunakan otot besar untuk menopang segala aktivitas sehari-hari. Contoh bentuk motorik kasar adalah berlari, menendang, dan melompat.

Perkembangan motorik anak sangat penting untuk diperhatikan karena sesuai dengan karakteristik anak yaitu bermain sehinga dibutuhkan keterampilan motorik yang baik guna menunjang aktivitas sehari-hari anak. Keterampilan motorik juga berfungsi untuk membuat tubuh anak menjadi lebih sehat dan perkembangan tubuhnya berjalan dengan baik karena ia mampu bergerak dengan baik yang ditandai dengan keaktifan anak dalam bermain. Anak yang aktif selain berguna untuk kesehatan dan perkembangan tubuh yang ideal juga mengajarkan anak untuk bersosialisasi dan berinteraksi dengan lingkungan yang berguna untuk membentuk karakter anak dan mempermudah anak dalam berinteraksi dengan lingkungan sekitar.

Aktivitas fisik tak hanya berpengaruh terhadap tingkat kesehatan namun juga pada kemampuan kognitif, emosi, dan sosial anak berdasarkan berbagai penelitian. Pagani \& Messier (2012) menyampaikan bahwa meskipun secara umum kemampuan motorik anak sering kali diabaikan dalam konsep kesiapan sekolah karena sekolah umumnya hanya terfokus pada kemampuan kognitif dan emosi anak, akan tetapi berdasarkan hasil penelitiannya ditemukan bahwa kemampuan motorik (baik motorik kasar maupun motorik halus) berhubungan dengan kemampuan-kemampuan lainnya yang merupakan syarat dari kesiapan sekolah seperti kemampuan verbal, sosial, kemampuan matematika awal, dan keterampilan berperilaku.

Kemampuan gerak merupakan aktivitas yang sangat penting bagi manusia, karena dengan gerak manusia dapat meraih sesuatu yang menjadi harapannya. Menurut Widiyastuti (2014) Konsep pembelajaran gerak merupakan dasar bagi pelaksanaan proses pembelajaran dan pelatihan gerak atau keterampilan gerak. Keterampilan gerak adalah kemampuan untuk melakukan gerakan secara efisien serta perwujudan dari kualitas koordinasi dan kontrol atas bagian bagian tubuh yang terlibat dalam gerakan. 
Dalam Proses latihan erat kaitannya dengan belajar gerak. Menurut gallahue ( 2006) Belajar gerak (motor learning) adalah merupakan perubahan yang relatif permanen dalam kinerja atau berhubungan dengan perubahan perilaku gerak yang dihasilkan berkat latihan atau pengalaman di masa lalu.Menurut Rink (2010), belajar gerak diartikan sebagai suatu perubahan keadaan diri seseorang yang berupa peningkatan keterampilan secara relatif tetap sebagai hasil latihan atau pengalaman.

Pembelajaran gerak adalah serangkaian proses yang dihubungkan dengan latihan atau pengalaman yang mengarah pada perubahan perubahan yang relatif permanen dalam kemampuan seseorang untuk menampilkan gerakan gerakan yang terampil. Berdasarkan pada beberapa pengertian yang telah dikemukakan, maka dapat disimpulkan bahwa belajar keterampilan gerak dapat dipengaruhi oleh proses pembelajaran dan pengalaman dan keterampilan gerak merupakan proses latihan yang bertujuan untuk merubah kemampuan agar dapat melakukan gerakan gerakan yang diinginkan dengan baik.

Anak pada usia 6-8 tahun merupakan masa perkembangan yang pesat untuk motorik kasar dan motorik halus anak. Pada masa ini ini anak akan aktif dalam bergerak berupa kegiatan yang dilakukan sendiri dengan otot besar mulai berkembang dengan aktifitas yang dilakukannya.

Menurut Wijaya (2009) masa kecil disebut sebagai masa ideal untuk mempelajari keterampilan motorik karena: 1) tubuh anak lebih lentur daripada tubuh orang dewasa sehingga anak lebih mudah menguasai keterampilan motorik daripada orang dewasa. 2) anak belum banyak memiliki keterampilan yang akan berbenturan dengan keterampilan yang baru dipelajarinya, sehingga anak lebih mudah mempelajari keterampilan baru, 3) secara keseluruhan anak lebih berani mencoba pada saat kecil ketimbang saat dewasa, oleh karena itu mereka berani mencoba sesuatu yang baru sehingga menimbulkan motivasi yang diperlukan untuk belajar. 4) Anak -anak menyukai pengulangan, sehingga mereka bersedia mengulangi tindakan hingga otot terlatih untuk melakukannya secara efektif. 5) Anak memiliki waktu yang lebih banyak untuk mempelajari keterampilan motorik. 
Menurut Widiastuti (2011) kemampuan motorik adalah sebagai suatu kapasitas dari seseorang yang berkaitan dengan pelaksanaan kemampuan fisik untuk dapat melaksanakan suatu gerakan, atau dapat pula didefinisikan bahwa kemampuan motorik adalah kapasitas penampilan seseorang dalam melakukan suatu gerak. Menurut Yudanto (2010) dalam belajar motorik anak-anak memerlukan pengalaman keterampilan dasar (lokomotor, non-lokomotor, dan manipulatif) anak harus belajar melakukan gerakan sederhana sebelum menghubungkannya kedalam gerakan yang lebih rumit. Sebelum menguasai sebuah keterampilan gerak anak-anak harus diberikan latihan. Anak-anak harus memiliki kesempatan untuk mencoba, membetulkan dan mencoba lagi. Anak-anak akan memperbaiki keterampilan motoriknya berdasarkan pengalaman bermain yang dilakukan sebelumnya. Ingatan berperan penting bagi anak dalam mempelajari keterampilan motorik.

Kesimpulan pendapat di atas adalah bahwa belajar gerak adalah seperangkat proses yang berhubungan dengan latihan dan pengalaman yang mengantarkan kearah perubahan permanen dalam prilaku terampil. Dalam proses belajar gerak ada tiga tahapan yang harus dilalui oleh siswa untuk mencapai tingkat keterampilan yang sempurna (otomatis). Karena sangat pentingnya perkembangan motorik untuk anakanak sebagai salah satu perkembangan anak sehingga diperlukan bentuk pembelajaran atau latihan guna meningkatkan keterampilan motorik anak. Bentuk latihan dan pembelajaran motorik ini disesuaikan dengan karakteristik anak yaitu dalam bentuk permainan yang menyenangkan. Dalam hal ini peneliti melakukan penelitian tentang pengembangan model gerak dasar keterampilan motorik untuk anak usia 6-8 tahun.

Pada usia ini menanamkan kecintaan terhadap ilmu pengetahuan sangatlah muda, bahkan menurut Jean Piaget dan Inhelder (2010), usia sekolah dasar terdapat progresi berkesinambungan dari gerakan dan refleks spontan ke kebiasaan yang diperoleh, dan dari kebiasaan itu menuju kecerdasan.Karakteristik anak-anak adalah anak yang suka bermain. Dunia anak adalah dunia bermain dan belajarnya anak sebagian besar melalui permainan yang mereka lakukan. Bermain memiliki fungsi 
sebagai sarana refreshing untuk memulihkan tenaga seseorang setelah lelah bekerja dan dihinggapi rasa jenuh.

Berdasarkan tahap-tahap perkembangan anak berada pada tahap operasional konkret. Pada tahap ini, kemampuan anak untuk berpikir secara logis semakin berkembang. Asalkan obyek yang menjadi sumber berpikirnya adalah obyek nyata atau konkret. Karakteristik anak usia sekolah dasar tidak hanya itu. Menurut Sumantri dan Sukmadinata dalam Wardani (2012), karakteristik anak usia sekolah dasar yaitu: (1) senang bermain; (2) senang bergerak; (3) senang bekerja dalam kelompok; dan (4) senang merasakan atau melakukan sesuatu secara langsung. Berdasarkan pendapat diatas dapat disimpulkan bahwa siswa SD berada pada masa anak-anak yaitu masa dimana mereka memiliki karakteristik bermain yang menyenangkan sehingga model pembelajaran/latihan hendaknya disusun sesuai dengan karakteristik mereka yaitu dengan variasi permainan yang menyenangkan.

Metode penelitian dan pengembangan adalah metode penelitian yang digunakan untuk menghasilkan rancangan produk baru, menguji keefektifan produk yang telah ada, serta mengembangkan dan menciptakan produk baru.Menurut Sukmadinata (2005:164) menjelaskan bahwa penelitian dan pengembangan adalah "suatu proses atau langkah-langkah untuk mengembangkan suatu produk baru atau menyempurnakan produk yang telah ada yang dapat dipertanggungjawabkan”.

Penelitian pengembangan menurut Maksum (2012) adalah:“Suatu penelitian yang bertujuan untuk mengembangkan suatu produk baru atau menyempurnakan produk yang telah ada. Istilah produk bisa berarti perangkat keras (hardware) atau perangkat lunak (software). Penelitian pengembangan umumnya bersifat siklus yang diawali dengan adanya kebutuhan, kebutuhan tersebut dapat diselesaikan dengan pengembangan produk, dan untuk menghasilkan produk yang terpercaya perlu dilakukan pengujian beberapa kali”.

Langkah-langkah untuk mengembangkan produk atau menyempurnakan produk yang sudah ada dapat dilakukan dengan menganalisa kebutuhan. Peneliti dapat mendesain konsep yang akan dikembangkan dengan menganalisa kebutuhan. Proses 
tersebut agar hasil penelitian dapat mencapai hasil yang diinginkan dan menyempurnakan hasil produk sebelumnya.

Tujuan pada penelitian pengembangan ini adalah untuk: 1) menghasilkan produk berupa bentuk latihan untuk meningkatkan keterampilan motorik anak yang sesuai dengan tahapan usia 6-8 tahun dan sesuai dengan karakteristik anak-anak. 2) mengetahui keefektifan produk yang dihasilkan dalam peningkatan keterampilan motorik anak usia 6-8 tahun. Penelitian ini menghasilkan produk berupa bentuk latihan untuk meningkatkan motorik anak yang dikemas sesuai dengan karakteristik anak yaitu dengan bentuk permainan yang menyenangkan. Harapannya dengan bentuk model pengembangan motorik anak ini dapat menjadi salahsatu cara untuk mengembangkan motorik anak.

\section{METODE}

Penelitian pengembangan ini menggunakan model penelitian dan pengembangan (Research and Development) dari Borg dan Gall (1983:775)

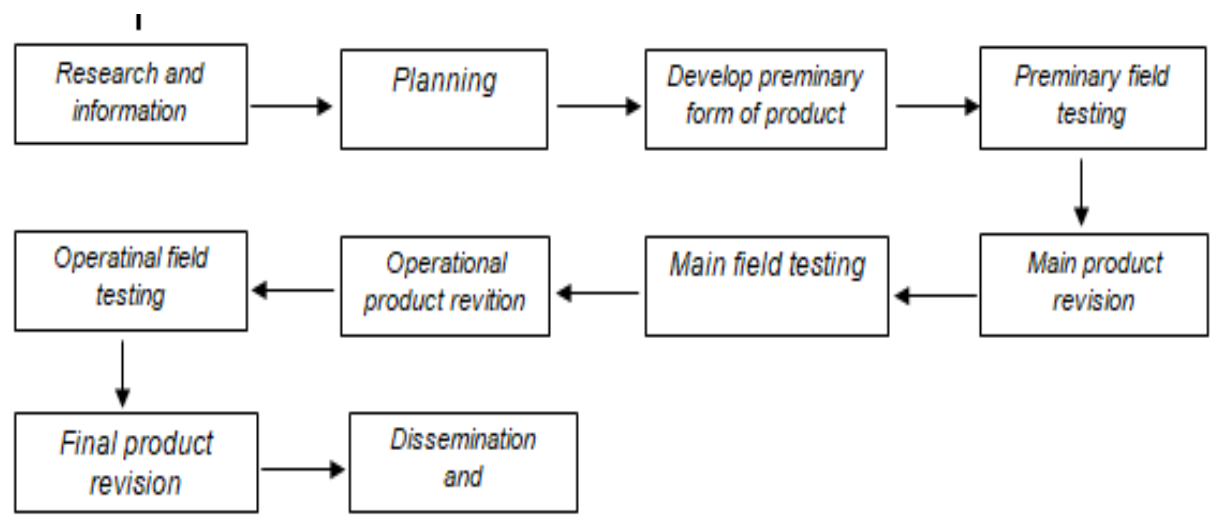

Gambar 1. Chart Langkah-Langkah Pengembangan Adaptasi dariBorg, W.R dan Gall, M.D. 1983. Educational Research An Introduction. New York:Longman.

Langkah-langkah penelitian dan pengembangan yang dikembangkan meliputi :

1) Pertama adalah menentukan masalah atau potensi yang menjadi dasar pengembangan model

2) Selanjutnya dilakukan pengumpulan informasi sebagai landasan pemikiran dalam pembuatan konsep 
3) Pembuatan model pembelajaran (rancangan produk), bentuk rancangan tersebut adalah model gerak dasar kterampilan motorik

4) Validasi desain, dilakukan oleh ahli yang bersangkutan,

5) Revisi, dari hasil uji ahli (validasi desain)

6) Ujicoba produk, dilakukan dengan mempraktekkan model latihan model gerak dasar keterampilan motorik

7) Revisi hasil uji coba produk

8) Ujicoba pemakaian atau uji kelompok yang lebih besar

9) Revisi produk kedua, revisi dilakukan oleh ahli, guna memperoleh hasil yang sempurna

10) Model dapat diproduksi

\section{Penelitian Pendahuluan}

Penelitian pendahuluan dilakukan dengan studi literatur, studi pengumpulan data lapangan, pengamatan proses, identifikasi permasalahan yang dijumpai dan deskripsi serta temuan dilapangan. Hasil ini dipergunakan untuk mengkaji keadaan lapangan dengan tujuan untuk mengetahui apakah produk yang akan dikembangkan ini nantinya dipergunakan oleh subjek, artinya model yang dikembangkan oleh peneliti diperlukan atau tidak.

Peneliti juga akan melakukan penjajakan dengan subjek penelitian dan tempat penelitian dan pengembangan untuk memperoleh hasil di lapangan. Hasil tersebut akan di analisis sehingga memperoleh kesimpulan data yang sudah terkumpul.Temuan penting yang hendak dideskripsikan dan dianalisis adalah bagaimanakah model (faktual) model gerak dasar kterampilan motorik yang saat ini dilaksanakan, serta apakah kelemahan dan kelebihannya berdasarkan model konseptual (karakteristik dan kriteria) gerak dasar kterampilan motorik dalam penelitian dan pengembangan ini.

\section{Perencanaan Pengembangan Model}

Langkah selanjutnya adalah membuat produk awal berupa rangkaian pengembangan model gerak dasar keterampilan motorik yang nantinya dapat dijadikan sebagai pedoman atau petunjuk untuk mempermudah proses latihanmodel gerak dasar 
keterampilan motorik sehingga dapat memperoleh hasil yang baik. Produk awal tersebut dituangkan dalam model latihangerak dasar keterampilan motorik. Pengembangan model latihan diharapkan menjadi produk yang dapat dikembangkan secara sistematis dan logis, sehingga produk ini mempunyai keefektifan dan keefisienan yang layak digunakan. Pada pembuatan produk yang peneliti kembangkan, peneliti harus konsultasi tentang produk pada ahliperkembangan motorik, agar dapat menghasilkan produk yang sempurna.

Model ini menekankan pada model yang lebih mudah, menarik, menyenangkan, dan tidak membosankan yang sesuai dengan karakteristik anak sehingga dapat membantu dalam meningkatkan keterampilan motorik anak.

\section{Validasi, Evaluasi dan Revisi Model}

Langkah selanjutnya dalam penelitian riset dan pengembangan model model gerak dasar kterampilan motorik adalah:

\section{a. Telaah Pakar (Expert Judgement)}

Telaah Pakar dalam model gerak dasar keterampilan motorik berguna untuk mengevaluasi bagian-bagian dari model yang perlu diperbaiki, dihilangkan atau disempurnakan, hal ini dilakukan pada hasil rancangan dalam bentuk rancangan tulisan gambar maupun dari teknik peragaan langsung di lapangan saat perancangan model. Pakar yang dilibatkan dalam penelitian $R$ and $D$ ini adalah 3 pakar, yakni 2 orang pakar perkembangan motorik dan 1 orang pakar pembelajaran. Hasil dari evaluasi dari pakar akan dijadikan masukan dalam menyempurnakan rancangan model model gerak dasar keterampilan motoriksebelum dilakukan uji coba kepada kelompok kecil.

b. Uji coba kepada kelompok kecil (small group try-out)

Pelaksaan uji coba kelompok kecil dilakukan dengan subjek 30anak kelompok usia 6-8 tahun, anak melakukan model gerak dasar keterampilan motorikdengan model latihan yang telah di kembangkan. 
C. Revisi

Setelah melaksanakan ujicoba kelompok kecil, hasilnya dijadikan sebagai bahan untuk memperbaiki model latihangerak dasar keterampilan motoriksebelum di uji cobakan lapangan. Hasil yang dilakukan pada uji kelompok kecil merupakan evaluasi yang kedua setelah evaluasi dari para pakar sebelumnya.

d. Uji coba lapangan (field try-out)

Kegiatan selanjutnya adalah melakukan uji coba lapangan atau uji coba kelompok besar, dalam kegiatan lanjutan penelitian riset dan pengembanganmodel gerak dasar keterampilan motorik adalah ujicoba lapangan. Ujicoba lapangan dilakukan setelah model latihan direvisi dari hasil uji coba sebelumnya.

Uji coba lapangan dilakukan pada anak kelompok usia 6-8 tahun sebanyak 50 Subjek.

e. Revisi

Hasil kesimpulan yang diperoleh dari ujicoba lapangan merupakan landasan terakhir dari perbaikan dan penyempurnaan produk model gerak dasar keterampilan motorik. Hasil respon dari para anak setelah melakukan latihan secara langsung diberikan sebagai masukan evaluasi perbaikan model.

Evaluasi pada tahapan ini merupakan evalusi akhir dari model gerak dasar keterampilan motorik ini. setelah perbaikan berdasarkan masukan dari uji lapangan, maka produk model gerak dasar keterampilan motorikdianggap layak untuk disebarkan atau digunakan.

\section{Teknik Pengumpulan Data dan Uji Efektifitas Produk}

Uji coba ini bertujuan untuk untuk mengetahui apakah desain model telah diterapkan dengan baik dan benar, dan seberapa efektif hasil penerapan model terhadap tujuan penelitian ini. Efektivitas produk didapatkan berdasarkan penilaian yang dilakukan oleh 3 orang ahli terhadap model yang dikembangkan. Penilaian tersebut berupa angket yang diberikan kepada setiap ahli untuk menilai kelayakan dari produk yang dikembangkan. cara menskor hasil dari seluruh instrument penilaian adalah sebagai berikut:

$$
\Sigma=\frac{\text { skor maksimal yang didapat }}{\text { skor maksimal }} \times 100 \%
$$


Tabel 1. Analisis Persentase Hasil Evaluasi Ahli

\begin{tabular}{cll}
\hline Persentase & Keterangan & \multicolumn{1}{c}{ Makna } \\
\hline $85-100$ & Sangat baik & Digunakan \\
$69-84$ & Baik & Digunakan \\
$53-68$ & Cukup baik & Digunakan bersyarat \\
$37-52$ & Kurang baik & Diperbaiaki \\
$<37$ & Tidak baik & Dibuang \\
\hline
\end{tabular}

Sumbèr : Silälahi 2̂̃ộ (D̄ianawâti, dkk: 2017)

\section{HASIL PENELITIAN}

Validasi ahli dilakukan dalam dua tahap. Tahap yang pertama adalah evaluasi dan penilaian produk awal sebelum dilakukan uji coba skala kecil. Tahap yang kedua adalah evaluasi dan validasi produk uji coba skala kecil untuk diuji cobakan pada skala besar. Instrument dalam penelitian berdasarkan dari validasi dari para ahli. Tujuannya adalah untuk mendapatkan kelayakan model yang akan dikembangkan berdasarkan dari hasil konsultasi dan penilaian dari 3 orang ahli tersebut. Dimulai dari perencanaan model yang akan dikembangkan selanjutnya dihasilkan produk awal berupa model gerak dasar keterampilan motorik, selanjutnya dilakukan dari ujicoba kelompok kecil sampai dengan ujicoba kelompok besar hingga produk hasil pengembangan dinyatakan layak untuk dipublikasikan dan disebarluaskan. Dibawan ini akan disajikan hasil penilaian dari para ahli sebagai berikut:

Berikut ini akan disajikan data hasil dari validasi ahli motorik terhadap rancangan model gerak dasar keterampilan motorik.Berdasarkan penilaian dari ahli perkembangan motorik yaitu 3 orang dosen dengan rincian 2 orang ahli perkembangan motorikdan 1 orang ahli pembelajaran dengan mengisi instrument kuisioner yang berupa pertanyaan dengan jumlah 10 pertanyaan, yang masing-masing pertanyaan memiliki skor maksimal 5 dan skor minimal 1. Skor maksimal dari keseluruhan pertanyaan adalah 50 dan skor minimal adalah 10 yang akan dikonvert ke skor nilai

Berikut adalah hasil dari penilaian 3 orang ahli:

1. Ahli Perkembangan Motorik

$$
\begin{aligned}
& \Sigma=\frac{\text { skor maksimal yang didapat }}{\text { skor maksimal }} \times 100 \% \\
& \Sigma=\frac{45}{50} \times 100 \%
\end{aligned}
$$




$$
=90 \%
$$

Berdasarkan hasil yang diperoleh dari penilaian ahli senam adalah $90 \%$ yang berarti sangat baik dan layak untuk digunakan.

2. Ahli Perkembangan Motorik

$$
\begin{aligned}
\sum & =\frac{\text { skor maksimal yang didapat }}{\text { skor maksimal }} \times 100 \% \\
\Sigma & =\frac{42}{50} \times 100 \% \\
& =84 \%
\end{aligned}
$$

Hasil yang diperoleh berdasarkan penilaian ahli pembelajaran adalah $82.8 \%$ yang berarti baik dan layak untuk digunakan.

3. Ahli Pembelajaran

$$
\begin{aligned}
\sum & =\frac{\text { skor maksimal yang didapat }}{\text { skor maksimal }} \times 100 \% \\
\Sigma & =\frac{46}{50} \times 100 \% \\
& =92 \%
\end{aligned}
$$

Hasil yang diperoleh berdasarkan penilaian ahli bahasa adalah $86.6 \%$ yang berarti sangat baik dan layak untuk digunakan.

Data diatas adalah penilaian model latihan yang dihasilkan dari 3 orang expert judgement. Berikut ini adalah rekapitulasi nilai dari expert judgement tersebut:

Tabel 2. Rekapitulasi nilai dari expert judgement

\begin{tabular}{clc}
\hline No & \multicolumn{1}{c}{ Expert Judgement } & Nilai \\
\hline $\mathbf{1}$ & Ahli Perkembange) \\
\hline $\mathbf{2}$ & Ahli Perkembangan Motorik & $90 \%$ \\
\hline $\mathbf{3}$ & Ahli Pembelajaran & $84 \%$ \\
\hline Rata-rata & $92 \%$ \\
\hline
\end{tabular}

Berdasarkan data diatas yaitu nilai rata-rata yang dihasilkan dari para ahli sebesar 88,6 \% sehingga model gerak dasar keterampilan motorik ini dinyatakan sangat baik dan layak untuk digunakan. 


\section{KESIMPULAN}

Berdasarkan hasil analisis berdasarkan penilaian ahli maka dapat disimpulkan bahwa bentuk pengembangan model gerak dasar motorik untuk usia 6-8 tahun ini layak digunakan. Hasil akhir dalam penelitian ini berupa buku panduan pelaksanaan item model gerak dasar motorik yang berisi tujuan, pelaksanaan, pengamatan, dan video pelaksanaan model gerak dasar motorik untuk usia 6-8 tahun

\section{DAFTAR PUSTAKA}

Borg Walter R., and Gall M.D. (1983). Educational Research: An Introduction. New York: Longman Inc.

Dianawati, Ita. Dkk. (2017). Pengembangan Alat Sensor Gerak pada Garis Servis Double Event dalam Permainan Sepaktakraw. Journal of Physical Education and Sports 6 (3).

Gallahue, David L., Ozmun, John C. (2006). Understanding Motor Development. Boston: MC.Graw-Hill.

Maksum, Ali. (2012). Metode Penelitian dalam Olahraga. Surabaya: Unesa University Press.

Pagani, L. S., \& Messier, S. (2012). Links between Motor Skills and Indicators of School Readiness at Kindergarten Entry in Urban Disadvantaged Children. Journal of Educational and Developmental Psychology. 2(1).

Piaget, Jean \& Barbel, Inhelder. (2010). Psikologi Anak. Yogyakarta: Pustaka Pelajar.

Rink, Judith E. (2010). Teaching Physical Education for Learning, $6^{\text {th }}$ edition. New York: McGraw-Hill Co, Inc.

Sugiyono. (2015). Metode Penelitian dan Pengembangan. Bandung: Alfabeta.

Tangkudung, James. (2016). Macam-Macam Metodologi Penelitian Uraian dan Contohnya. Jakarta:Lensa Media Pustaka Indonesia.

Walter R. Borg, and Meredith D. Gall,. (1983). Educational Research: An Introduction, $4^{\text {th }}$ Edition. New York: Longman Inc.

Wardani, Dani. (2009). Bermain Sambil Belajar. Jakarta: Edukasia.

Widiyastuti. (2014). Belajar Keterampilan Gerak. Jakarta: FIK Universitas Negeri Jakarta. 
Wijaya, Awi M. (2009). Pentingnya Stimulasi, Deteksi dan Intervensi Dini tumbuhKembang (SDIDTK) Anak. Jakarta: Depdiknas.

Yudanto (2010). Stimulasi Gerak Dasar Siswa Sekolah Dasar Kelas Bawah. Jurnal PendidikanJasmani Indonesia, Volume 4, Nomor 2, Nopember 2007. FIK UNY 